\title{
Wind and tidal influences on larval crab recruitment to an Oregon estuary
}

\author{
G. Curtis Roegner ${ }^{1, *}$, David A. Armstrong ${ }^{2}$, Alan L. Shanks ${ }^{3}$ \\ ${ }^{1}$ NOAA Fisheries, Northwest Fisheries Science Center, Point Adams Biological Field Station, PO Box 155, \\ Hammond, Oregon 97013, USA \\ ${ }^{2}$ School of Aquatic and Fisheries Science, PO Box 355020, University of Washington, Seattle, Washington 98195, USA \\ ${ }^{3}$ University of Oregon, Oregon Institute of Marine Biology, PO Box 5389, Charleston, Oregon 97420, USA
}

\begin{abstract}
We investigated wind and tidal forcings that may facilitate transport of crab megalopae to a northeast Pacific coastal estuary. Daily abundance of crab megalopae was estimated from light trap collections made from March 1998 through December 2001 in Coos Bay, Oregon, USA. The Dungeness crab Cancer magister dominated the catch; Cancer Group I (C. productus and C. oregonensis), Hemigrapsus oregonensis and Pachygrapsus crassipes megalopae were also abundant enough for statistical evaluation. The abundance time series data were analyzed in relation to mean daily wind stress, maximum daily tidal range, and mean daily temperature residuals using cross-correlation and cross-Fourier techniques. Variation in wind stress had little relation to variation in crab megalopae abundance. Rather, crab megalopae were found to recruit to the estuary at periods close to the spring-neap tidal frequencies. Increased catches were not coincident with spring tides; most tests indicated that ingress occurred at times ranging from several days after spring tide to near the neap tide, but this varied among species and years. Tidal forcing appears to control crab recruitment to this estuarine system.
\end{abstract}

KEY WORDS: Ocean-estuary coupling · Larval transport · Cancer magister • Hemigrapsus oregonensis $\cdot$ Pachygrapsus crassipes $\cdot$ Light trap $\cdot$ Northeast Pacific

\section{INTRODUCTION}

Along the northeast Pacific coast of North America, larvae of most estuarine and coastal crab species undergo a relatively long oceanic larval phase lasting from weeks to several months. This pelagic period includes the dispersive zoeal stages and the terminal, recruiting megalopal stage. Zoea and megalopae are morphologically and behaviorally distinct; zoea are adapted for pelagic life, whereas megalopae are specialized to find suitable benthic settlement sites. To achieve life-history closure (Sinclair 1988), megalopae must migrate from open-ocean and shelf environments to nearshore or estuarine benthic habitats. Variation in the numbers of mature larvae that complete this migration may determine future population structure, a condition known as recruitment-limitation (Connell 1985).
There are long standing questions of how crab taxa in the northeast Pacific and elsewhere accomplish migration from pelagic habitats to settlement habitats (Queiroga \& Blanton 2004, Shanks \& Eckert 2005). These questions arise in part because ocean hydrodynamic fields are often strong and variable on many temporal scales (Largier et al. 1993) and horizontal velocities are typically far beyond that of even the most vigorous larval swimmer. Variations in wind stress and tidal forcing that create cross-shelf currents have been considered as mechanisms that megalopae can exploit to migrate towards shallow water settlement sites (Shanks 1995).

In the California Current System (CCS), seasonal weather patterns generate hydrographic regimes dominated by either downwelling or upwelling (Hickey 1989). During winter (November to March or April), 
the predominately poleward wind stress results in downwelling conditions on the coast. Surface currents on the continental shelf tend to move northward as the Davidson Current, while further offshore, the California Current is directed equatorward. At the 'spring transition', which usually occurs in March or April, wind patterns switch synoptically to a prevailing equatorward direction that favors upwelling and generates southward flow in the mean surface currents over the shelf (Strub et al. 1987). The timing of the spring transition each year appears to control inter-annual year class strength of some crab species (Shanks \& Roegner 2007). During October or November, a 'fall transition' back to winter downwelling conditions occurs, and the seasonal cycle repeats. Crab taxa recruit to northeast Pacific estuaries at different portions of the annual cycle.

Within this annual pattern of wind-driven currents are event-scale weather systems that generate strong Ekman circulation on the shelf. Typically, the dominant upwelling or downwelling (alongshore) winds are interspaced by wind relaxation or reversals (Huyer 1983, Strub et al. 1987). These wind events have relatively rapid ( $<1$ to $3 \mathrm{~d}$ ) impacts on nearshore and estuarine circulation patterns. In winter, strong downwelling events occur during storms, and upwelling events tend to be few in number and low in intensity. Downwelling tends to force warmer and fresher surface waters to accumulate adjacent to the coast. During the upwelling season, equatorward winds drive the warmer and fresher coastal water offshore and this is replaced by cold and salty subsurface water (Huyer 1983). A decline or directional change in the equatorward wind stress reverses these trends, and warmer, fresher water returns to the coast (Send et al. 1987). Previous studies in several northeast Pacific estuaries have demonstrated that water properties at the coast are rapidly transferred into estuaries (Roegner \& Shanks 2001, Roegner et al. 2002, Hickey \& Banas 2003). Wind-forced advective events can potentially cause a cross-shelf transport of larvae and may explain variation in larval recruitment to the coast (Roughgarden et al. 1991, Wing et al. 1995a,b) and then to estuaries.

Tidal forcing can also cause cross-shore advection of larvae. Several mechanisms of larval transport due to tidal factors have been identified. First is tidal stream transport, whereby larvae execute a vertical migration timed to coincide with the cross-shelf axis of the rotary tidal currents (Hill 1995). Tidal stream transport has been demonstrated to effect retention or migration of some crab taxa within estuaries (Forward \& Tankersley 2001) but has not yet been observed in continental shelf waters. Three other mechanisms of larval transport are due to baroclinic (internal) tides. The internal tides are generated by interactions of tidal currents with topography coupled with water column density structure and may take several forms: (1) shoreward transport in convergence zones over tidally-generated internal waves (Shanks 2002), (2) shoreward transport within a cold or warm bore of a broken internal wave (Pineda 1991, Leichter et al. 1998, Shanks \& McCulloch 2003), and (3) shoreward transport in the upwelling front associated with the arrival of a cold bore (Pineda 1999). The ability of each of these 4 tidal mechanisms to transport larvae depends on larval swimming behavior (e.g. neustonic orientation), and all 4 mechanisms have primary periods $<1 \mathrm{~d}$. Finally, as a purely passive mechanism, the higher volume flux of water entering an estuary during spring tides could lead to higher larval transport rates and settlement at these times than during neap tides.

We investigated whether wind and/or tidal mechanisms facilitate the cross-shelf transport and oceanestuary exchange of crab megalopae to Coos Bay, Oregon, USA. If so, larval abundance in the estuary should be related to the lagged physical driver. To test these possibilities, we used light traps to collect daily measurements of crab megalopae abundance over a $3.75 \mathrm{yr}$ period and analyzed the catch time series in relation to time series of mean daily wind stress and maximum daily tidal range. The specific goals of the study were (1) to determine the seasonal abundance patterns of crab megalopae in the Coos Estuary, (2) to test the correlation of larval crab abundance with physical drivers (wind stress and tidal forcing) and a response variable (estuarine temperature) using time series analysis, and (3) to test for periodic (tidal) signals in the larval crab abundance time series with spectral analysis.

\section{MATERIALS AND METHODS}

Study site. Coos Bay is a drowned river valley approximately $54 \mathrm{~km}^{2}$ in area with a watershed surface area of $1576 \mathrm{~km}^{2}$ (Fig. 1). The inlet to the nearshore zone (maximum depth of about $15 \mathrm{~m}$ ) is near the confluence of the mainstem Coos Bay and the subsidiary South Slough, a US National Estuarine Research Reserve. Rainfall in the region is highly seasonal and averages $140 \mathrm{~cm}$ between October and May, but declines to $<10 \mathrm{~cm}$ between June and September. River input varies accordingly from $\sim 150 \mathrm{~m}^{3} \mathrm{~s}^{-1}$ in winter to $<3 \mathrm{~m}^{3} \mathrm{~s}^{-1}$ in summer. The tides are mixed semidiurnal with mean amplitude of $2.3 \mathrm{~m}$ and because the average depth of the estuary is only $2 \mathrm{~m}, \sim 65 \%$ of the estuary is intertidal. Regions of the lower estuary are well flushed by tidal action and water properties in the lower estuary reflect coastal conditions during flood tides (Roegner \& Shanks 2002). 


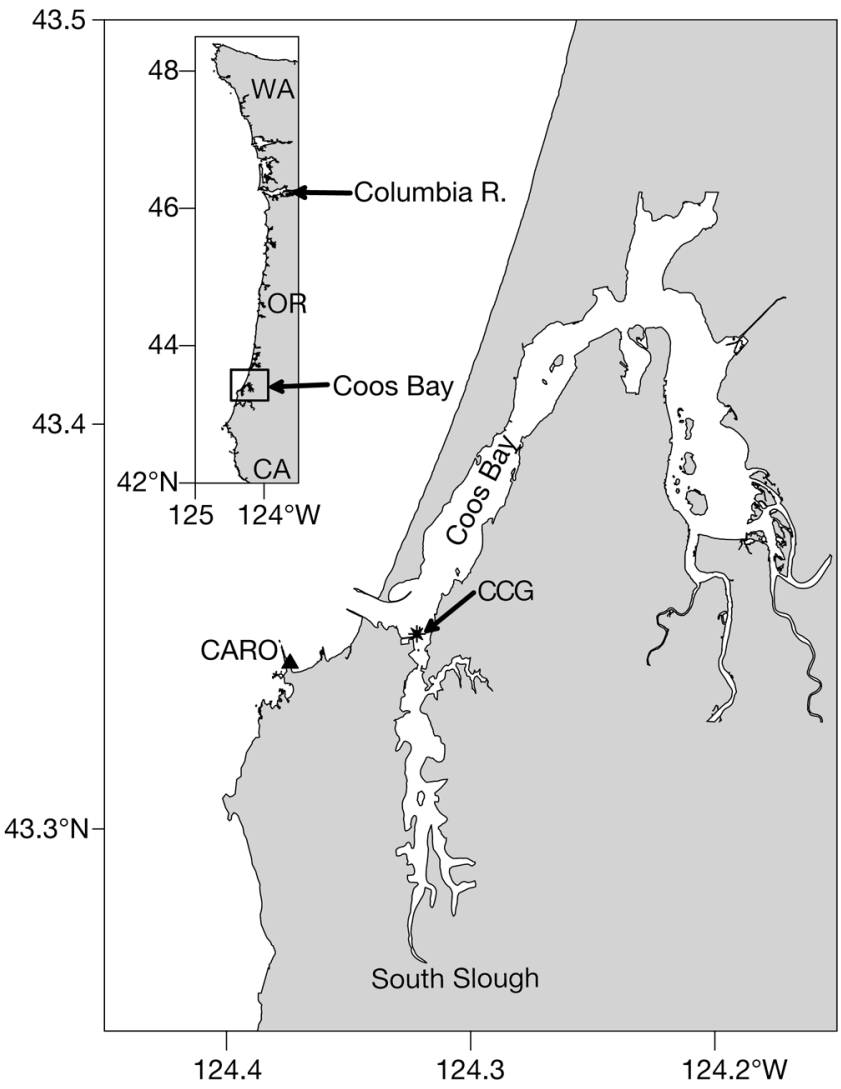

Fig. 1. Study area with light trap and instrument stations. CCG: Charleston Coast Guard dock with light trap and estuarine tidal and temperature station; CARO: Cape Arago meteorological station; WA: Washington State; OR: Oregon State; CA: California

Physical time series. Local winds, water level, and estuarine water temperature were measured hourly from automated sensors; these were averaged to daily values for statistical comparison with daily catch of megalopae (see below). Wind speed and direction were acquired from the C-MAN station at Cape Arago, Oregon, USA $\left(\mathrm{CARO} 3 ; 43.342^{\circ} \mathrm{N}, 124.375^{\circ} \mathrm{W}\right)$, located just south of the mouth of Coos Bay. We computed the mean daily wind stress $\left(T, \mathrm{~N} \mathrm{~m}^{-2}\right)$ from hourly observations as $T=p_{\mathrm{a}} C_{\mathrm{d}} U^{2}$ (Pedlosky 1987), where air density $p_{\mathrm{a}}$ was set at $1.18 \mathrm{~kg} \mathrm{~m}^{-3}$, the drag coefficient $C_{\mathrm{d}}$ at 0.002 , and velocity $U$ was measured in units of $\mathrm{m} \mathrm{s}^{-1}$. Wind stress was resolved into north-south and eastwest components, and we followed the oceanographic convention where wind components directed towards the north and east are positive. Maximum daily tidal range and mean daily water temperature were calculated from hourly measurements recorded at the NOAA (National Oceanic and Atmospheric Administration) tidal station located at the Charleston marina at the Coast Guard station pier (CCG, $43.345^{\circ} \mathrm{N}$,
124.323 ${ }^{\circ}$ W, Fig. 1). Variation in estuarine water temperature was used as a proxy to identify estuary-ocean exchange events. For clarity in the figures, wind stress and estuarine temperature were low-pass filtered ( $7 \mathrm{~d}$ moving average); further, the smoothed temperature time series are presented as deviations (TD) from the mean temperature of the 1997 to 2001 period. Smoothed data were not used for statistical analyses.

Larval time series. Larval crab abundance was monitored at the Charleston marina adjacent to the NOAA tidal station (Fig. 1). We made daily measurements from March 1998 through December 2002 using light traps (Roegner et al. 2003, Miller \& Shanks 2004), which are behavioral samplers that exploit the strong positive phototropism displayed by many marine plankton. The trap body was constructed from a semiopaque $19 \mathrm{l}$ plastic jug. Plankton gained entry through six $1 \times 3 \mathrm{~cm}$ openings cut into the apex of inverted translucent plastic funnels. Each trap was illuminated by a 6 -watt AC fluorescent bulb sealed in an acrylic tube. The traps were moored to floating docks and suspended just below the water surface. During retrieval (generally between 07:00 and 10:00 h), specimens were concentrated in a cod end (250 $\mu \mathrm{m}$ mesh) attached to the base of the trap body and then preserved in $10 \%$ buffered formalin for laboratory identification. The light traps were in a protected, low velocity location but were well within 1 tidal excursion of the mouth of the bay and were exposed to coastal ocean water on every flood tide. During 1998, dual traps were deployed and we found a good correlation between replicates $(r=0.92)$, in agreement with multiple traps deployed in 2 Washington estuaries during 1999 (Roegner et al. 2003). Thereafter we used a single trap. Time series of larval abundance were constructed for prominent crab species.

Time series analyses. We used cross-correlation and spectral analyses to test for coincidence of larval abundance with wind and tidal physical drivers. Crosscorrelations were used to identify temporal lags in the physical forcing (wind stress or maximum daily tidal range) and response variables. We could only run the larval analyses with a sufficiently large catch (see Results section). Catch was log (abundance +1) transformed to reduce heteroscadicity. We removed the seasonal trend from the original catch and temperature time series data and ran cross-correlations using the resultant residuals (Pyper \& Peterman 1998). Wind stress and maximum daily tidal range time series were not transformed for statistical analyses.

We first tested the effect of alongshore and crossshore wind stress and of maximum daily tidal range on estuarine temperature variation. These measure estuarine-coastal linkages. We then examined the significance of (1) alongshore and cross-shore wind, (2) max- 
imum daily tidal range, and (3) daily temperature residual time series in explaining the catch of megalopae. To interpret the results of the cross-correlations, we followed criteria developed in Roegner et al. (2003). The sign of the correlation coefficient was used to ascertain how water properties in the estuary responded to alongshore wind stress (i.e. upwelling versus downwelling), and we set boundaries on the valid time lag between forcing and response. Since the response variables 'temperature' and 'larvae' must follow wind and tide forcing, only time lags $\leq 0 \mathrm{~d}$ were considered valid. Based on previous studies (Roegner et al. 2003, Miller \& Shanks 2004), we limited our analysis of wind forcing to lags between 0 and $-4 \mathrm{~d}$, while for tidal forcing we examined lags between 0 and $-7 \mathrm{~d}$. We used cross-Fourier analysis to detect the presence of periodic tidal patterns in the various time series and to estimate the percent of the variation that could be attributed to the forcing. In the cross-Fourier analysis, the squared coherency can be interpreted as a squared correlation coefficient in correlation analysis and it provides an estimate of the percentage of the variability in the response variable at a given period that can be attributed to variation in the forcing variable (StatSoft 2005: STATISTICA [data analysis software system], version 7.1; www.statsoft.com).

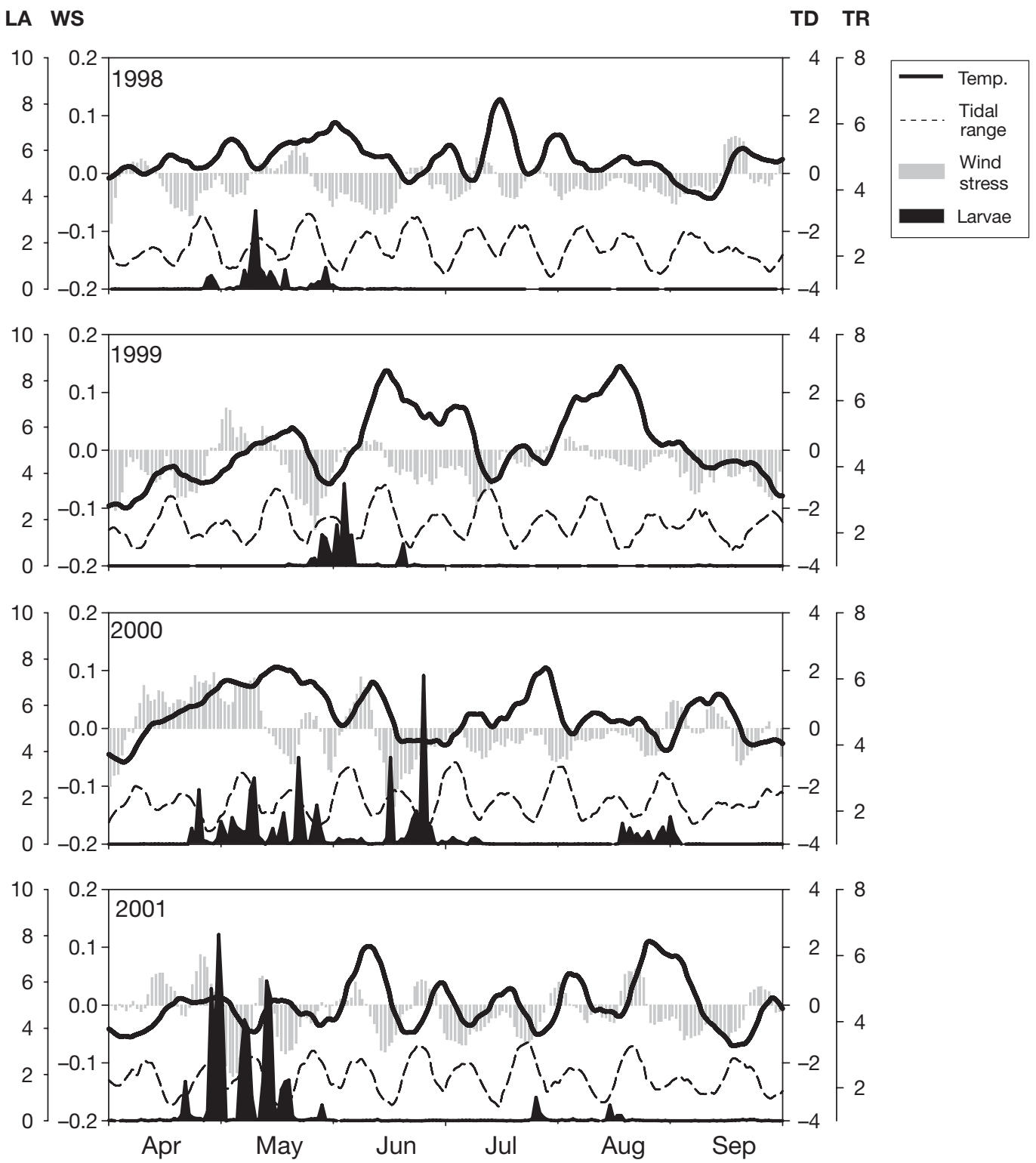

Fig. 2. Cancer magister. Time series of megalopae abundance (LA, $10^{3}$ ind. night ${ }^{-1}$ ), mean daily northward wind stress (WS, $\mathrm{N} \mathrm{m}^{-2}$ ), mean daily temperature deviation $\left(\mathrm{TD}^{\circ}{ }^{\circ} \mathrm{C}\right)$, and max. daily tidal range (TR, $\mathrm{m}$ ) for April to September from 1998 to 2001 


\section{RESULTS}

\section{Patterns of larval abundance}

Light traps were very effective in capturing a wide array of invertebrate holo- and meroplankton taxa, as well as over 23 species of larval and juvenile fishes. Here we concentrate on the 4 most abundant crab 'groups' sampled by the light traps. These include 3 species of cancrid crab megalopae, Cancer magister along with Cancer productus and Cancer oregonensis (which we could not distinguish and hereafter call Cancer group I), and 2 species of grapsid crab megalopae, Hemigrapsus oregonensis and Pachygrapus crassipes. Other prominent crab taxa not considered here were megalopae of $H$. nudus and Pagurus spp., and zoea of porcelainid crabs.

Within a recruitment season, catch of megalopae was generally pulsed, with large increases in abundance over several days separated by periods of low or zero counts. We term these pulses 'recruitment events'. The duration of individual recruitment events ranged from 2 to $>10 \mathrm{~d}$, and the number of pulses during an annual recruitment season was quite variable, ranging from a single episodic event to $>20$ individual events. The abundance of larvae within a pulse was also highly variable, and usually one to several large events accounted for the bulk of the annual recruitment, accompanied by smaller pulses with lower catches. A single short duration pulse could account for 20 to $90 \%$ of the annual catch.
Megalopae entered the estuary year round, but taxa had defined recruitment seasons. All the cancrid crab recruited during the spring-fall upwelling period (Figs. 2 \& 3). Hemigrapsus oregonensis had a broad abundance pattern concentrated in the fall transition but which included the summer upwelling period (Fig. 4). Pachygrapsus crassipes megalopae were caught exclusively during winter downwelling conditions (Fig. 5). There were large interannual variations in the timing, duration, and number of recruitment pulses among taxa. There were also large differences in total abundance among years, including apparent recruitment failure for several species. Overall, relatively good recruitment occurred in 1998 and 1999 for most species, while 2000 and 2001 were years of poor recruitment for all taxa except Cancer magister, for which exceptionally large catches were recorded.

\section{Species abundance}

Cancer magister (Dungeness crab) was by far the most abundant species sampled in light traps. Peak catches exceeded 8000 ind. trap $^{-1}$ night $^{-1}$, and we sampled over 150000 megalopae during the study. The bulk of the annual $C$. magister recruitment occurred over a 30 to $40 \mathrm{~d}$ period extending from late April through May. During 1999, a La Niña year, arrival was delayed until late May, and recruitment progressed through early June. Most megalopae were caught in pulses of 3 to $10 \mathrm{~d}$ duration during this spring recruit-
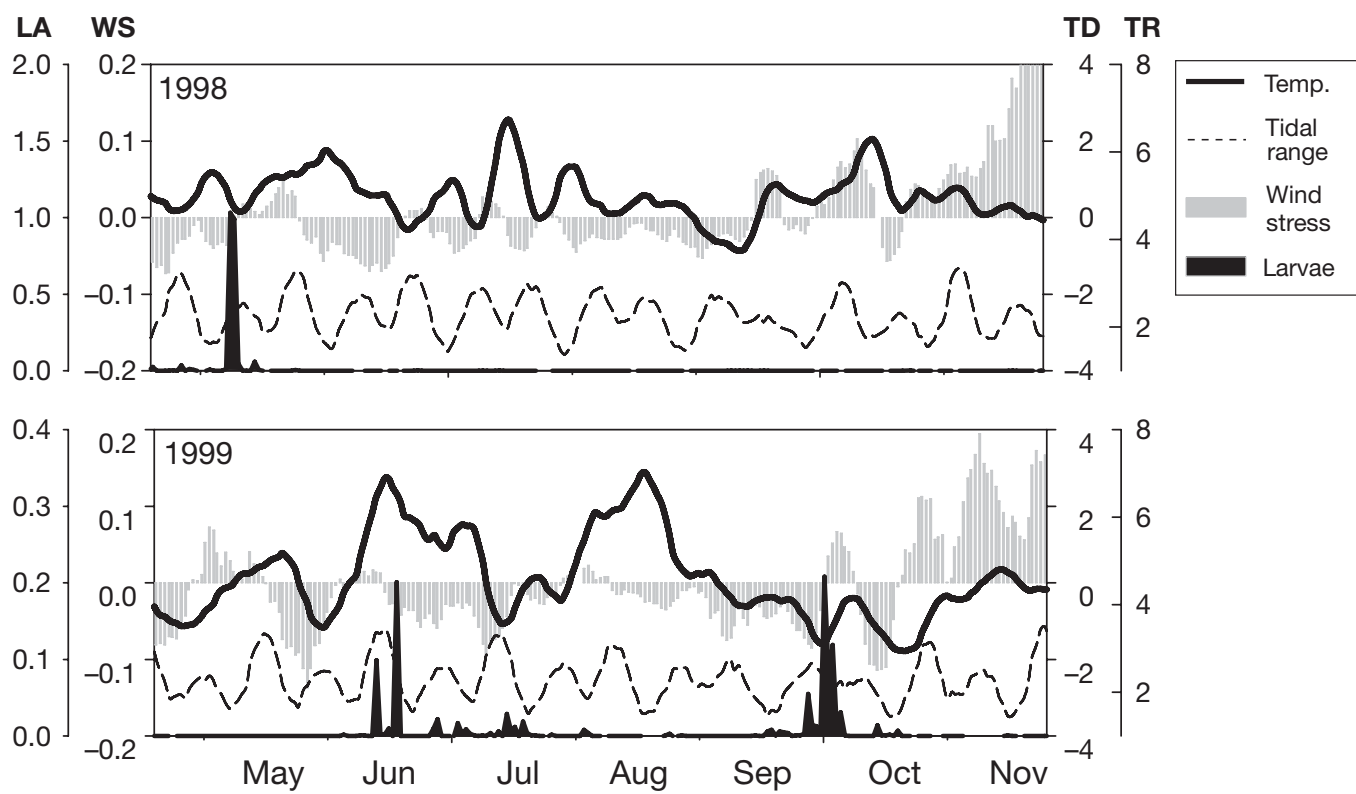

Fig. 3. Cancer spp. Time series of megalopae abundance (LA, $10^{3}$ ind. night ${ }^{-1}$ ), mean daily northward wind stress $\left(\mathrm{WS}, \mathrm{N} \mathrm{m}{ }^{-2}\right.$ ), mean daily temperature deviation $\left(\mathrm{TD}^{\circ}{ }^{\circ} \mathrm{C}\right)$, and max. daily tidal range $(\mathrm{TR}, \mathrm{m})$ for May to November in 1998 and 1999 


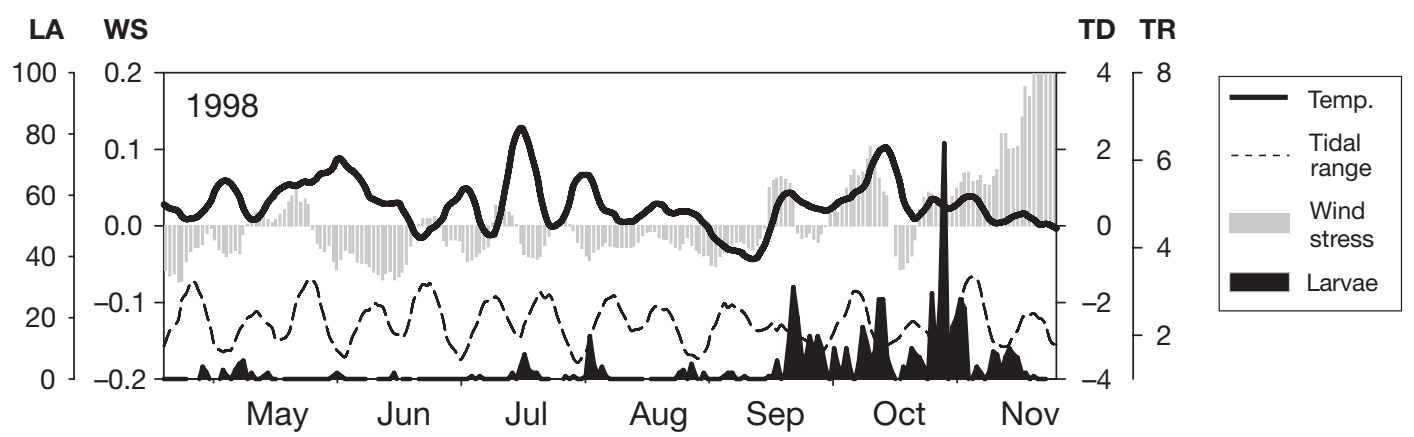

Fig. 4. Hemigrapsus oregonensis. Time series of megalopae abundance (LA, ind. night $\left.{ }^{-1}\right)$, mean daily northward wind stress (WS, $\mathrm{N} \mathrm{m}^{-2}$ ), mean daily temperature deviation $\left(\mathrm{TD},{ }^{\circ} \mathrm{C}\right)$, and max. daily tidal range $(\mathrm{TR}, \mathrm{m})$ for May to November 1998

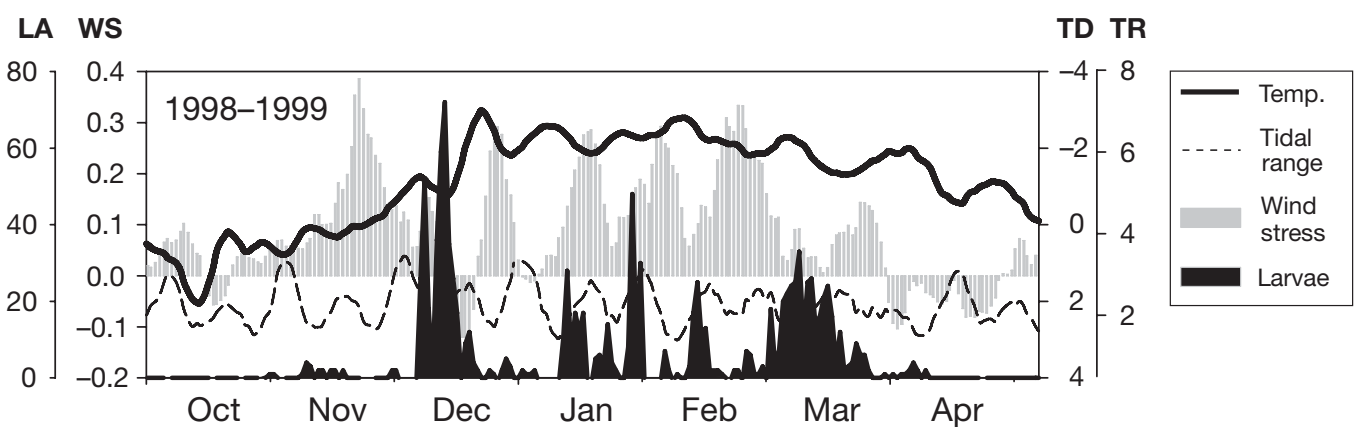

Fig. 5. Pachygrapsus crassipes. Time series of megalopae abundance (LA, ind. night ${ }^{-1}$ ), mean daily northward wind stress (WS, $\mathrm{N} \mathrm{m}^{-2}$ ), mean daily temperature deviation $\left(\mathrm{TD}^{\circ}{ }^{\circ} \mathrm{C}\right)$, and max. daily tidal range $(\mathrm{TR}, \mathrm{m})$ for October 1998 to April 1999

ment period. In 2000 and 2001, large pulses continued into late June, and low numbers of larvae continued to recruit throughout the summer. There were also occasional pulses during autumn, exceeding $2 \%$ of the annual total. The number of recruitment events per recruitment season varied from 3 to 14 over the 4 years. There were few pulses and lower overall recruitment in 1998 and 1999 (Fig. 2). There were more pulses and about a 3-fold higher abundance during 2000 and 2001 (Fig. 2). We used all 4 recruitment years of C. magister in our statistical analysis.

The annual abundance of Cancer Group I (red and pygmy rock crab) megalopae was very low in 2000 and 2001, with only 6 and 128 individuals sampled respectively during those years. Catch was much larger in 1998 and 1999, but in 1998 nearly all of the megalopae recruited during 1 short pulse in May (Fig. 3). In 1999, large catches occurred in June and at the end of September. Because of the low abundances in 2000 and 2001, statistical analysis was limited to 1998 and 1999.

The hairy shore crab Hemigrapsus oregonensis megalopae exhibited a wide temporal window and were present from April through November (Fig. 4), but the bulk of the larvae were caught in autumn (September to November). 1998 was the only year during which substantial numbers of $H$. oregonensis were caught (706), and statistical analysis was limited to data from this year.

The lined shore crab Pachygrapsus crassipes recruited from November to the beginning of April (Fig. 5) during the downwelling season. We sampled just the tail end of the 1998 recruitment season, and we captured very few individuals in 2000 and 2001 (25 and 27, respectively); statistical analysis was limited to the 1999 data set when we sampled the entire recruitment season and caught a significant number of megalopae.

\section{Physical drivers and estuarine temperature}

There were significant positive correlations of both northward and eastward wind stress on estuarine temperatures. Wind-induced temperature changes in the estuary were observed at -1 to $-4 \mathrm{~d}$ lags, with the highest correlations at -2 to -3 d lags. North- and eastward winds that set up downwelling conditions generally resulted in warmer estuarine temperatures, while winds blowing to the south or west generated upwelling conditions that resulted in colder estuarine temperatures. 
Table 1. Cross-correlation and cross-Fourier analyses between the max. daily tidal range and daily temperature residuals. Only significant lags are shown

\begin{tabular}{|c|c|c|c|c|}
\hline \multirow[t]{2}{*}{ Year } & \multicolumn{2}{|c|}{ Cross-correlation } & \multicolumn{2}{|c|}{ Cross-Fourier } \\
\hline & Lags (d) & $\mathrm{r}$ & $\begin{array}{l}\text { Cross-amplitude } \\
\text { period (d) }\end{array}$ & $\begin{array}{l}\text { Squared } \\
\text { coherency }\end{array}$ \\
\hline \multirow[t]{5}{*}{1998} & 0 & -0.16 & 14.0 & 0.39 \\
\hline & -1 & -0.16 & 14.6 & 0.58 \\
\hline & -2 & -0.14 & 15.2 & 0.55 \\
\hline & & & 14.0 & 0.13 \\
\hline & & & 14.6 & 0.38 \\
\hline \multirow[t]{3}{*}{1999} & & NS & 15.2 & 0.23 \\
\hline & & & 26.0 & 0.36 \\
\hline & & & 28.0 & 0.47 \\
\hline \multirow[t]{5}{*}{2000} & 0 & -0.13 & 14.1 & 0.28 \\
\hline & -1 & -0.20 & 14.6 & 0.65 \\
\hline & -2 & -0.24 & 15.9 & 0.52 \\
\hline & -3 & -0.24 & 28.2 & 0.40 \\
\hline & -4 & -0.20 & & \\
\hline \multirow[t]{6}{*}{2001} & -1 & -0.12 & 14.6 & 0.43 \\
\hline & -2 & -0.15 & 15.2 & 0.64 \\
\hline & -3 & -0.17 & 15.8 & 0.35 \\
\hline & -4 & -0.16 & 24.3 & 0.55 \\
\hline & & & 26.0 & 0.58 \\
\hline & & & 30.3 & 0.45 \\
\hline
\end{tabular}

In every year except 1999, we found significant negative cross-correlations between the maximum daily tidal range and the daily temperature residuals (Table 1). The cross-correlations suggest cold water events tended to occur at and just after the spring tides. In the cross-Fourier analyses, for all years we found a strong relationship between the maximum daily tidal range and temperature residuals (Table 1) at periods associated with the spring to neap cycle (i.e. around 14 and $28 \mathrm{~d}$ ). The cross-Fourier analysis suggests that from 13 to $65 \%$ (mean $44 \%$ ) of the variability in temperature can be attributed to variation in the maximum daily tidal range.

\section{Wind stress forcing and crab abundance}

Wind stress had a limited effect on the catch of megalopae in the estuary (Table 2). No significant cross-correlations were found between east-west wind stress (cross-shore stress) for any species in any year. Significant cross-correlations between north-south wind stress (alongshore stress) and catch were detected in 3 of 8 tests, but the results were not consistent in regards to wind direction or across years. For Hemigrapsus oregonensis in 1998, there was a small but significant positive cross-correlation between catch and alongshore wind stress at a lag of $-4 \mathrm{~d}$, suggesting a tendency for a slightly elevated catch following relaxation from upwelling wind events. Cancer Group I in 1999 had significant negative cross-correlations between catch and alongshore wind stress at lags of -1 to $-3 d$, indicating an association with upwelling conditions (i.e. winds from the north). Time series of Cancer magister abundance in 2000 exhibited significant negative correlations at lags of -3 and $-4 d$, suggesting that higher catches tended to occur several days after upwelling favorable winds. Pachygrapsus crassipes had no significant cross-correlations with wind events.

\section{Tidal range and crab abundance}

There were strong correlations between catch of megalopae and maximum daily tidal range across species and years. Significant cross-correlations were detected in 7 of 8 tests. However, megalopae entered the estuary at different periods of the spring-neap cycle. Cancer magister catches in 1998 and 2000 peaked 2 to 3 d after spring tide; in 1999 and 2001, catches were highest at lags of -5 to $-7 \mathrm{~d}$, i.e. near neap tide (Table 2). Cancer Group I abundance in 1998 was not significantly correlated with maximum daily tidal range (perhaps due to episodic entry); in 1999, Cancer Group I catches peaked 3 to $4 \mathrm{~d}$ after spring tides (between spring and neap) (Table 2). Catch of Hemigrapus oregonensis in 1998 had significant negative cross-correlations with the maximum daily tidal range at lags of 0 to $-3 \mathrm{~d}$, suggesting that peak catch occurred at and after neap tide, while Pachygrapsus crassipes had a negative correlation at -3 to $-7 \mathrm{~d}$ lag, suggesting that peak catch tended to occur between neap and spring tide and through the spring tide (Table 2).

Cross-Fourier analysis indicated catches were significantly more variable at spring-neap tidal frequencies. Cancer magister abundance had large crossamplitudes at periods around 14 and $28 \mathrm{~d}$ (Table 2). The squared coherency values at these periods suggest that from 38 to $90 \%$ (average $64 \%$ ) of the variability in the catch of C. magister at these periods could be explained by variation in the maximum daily tidal range. For Cancer Group I in both 1998 and 1999, we found large cross-amplitudes in the cross-Fourier analysis at periods around $14 \mathrm{~d}$ (Table 2); 27 to $57 \%$ of the variability in catch at these periods may be attributed to variation in the maximum daily tidal range. Hemigrapsus oregonensis in 1998 to 1999 had the largest cross-amplitudes at periods of 13.3 and $14.3 \mathrm{~d}$, and at these periods the squared coherency suggests that from 45 to $56 \%$ of the variability in catch at these periods may be attributed to variation in the maximum daily tidal range, respectively (Table 2). For Pachygrapsus crassipes in 1998 to 1999 the largest cross- 
Table 2. Cancer spp., Hemigrapsus oregonensis, Pachygrapsus crassipes. Cross-correlation and cross-Fourier analyses between the catch of megalopae and physical time series. Only significant lags are shown. NS = not significant

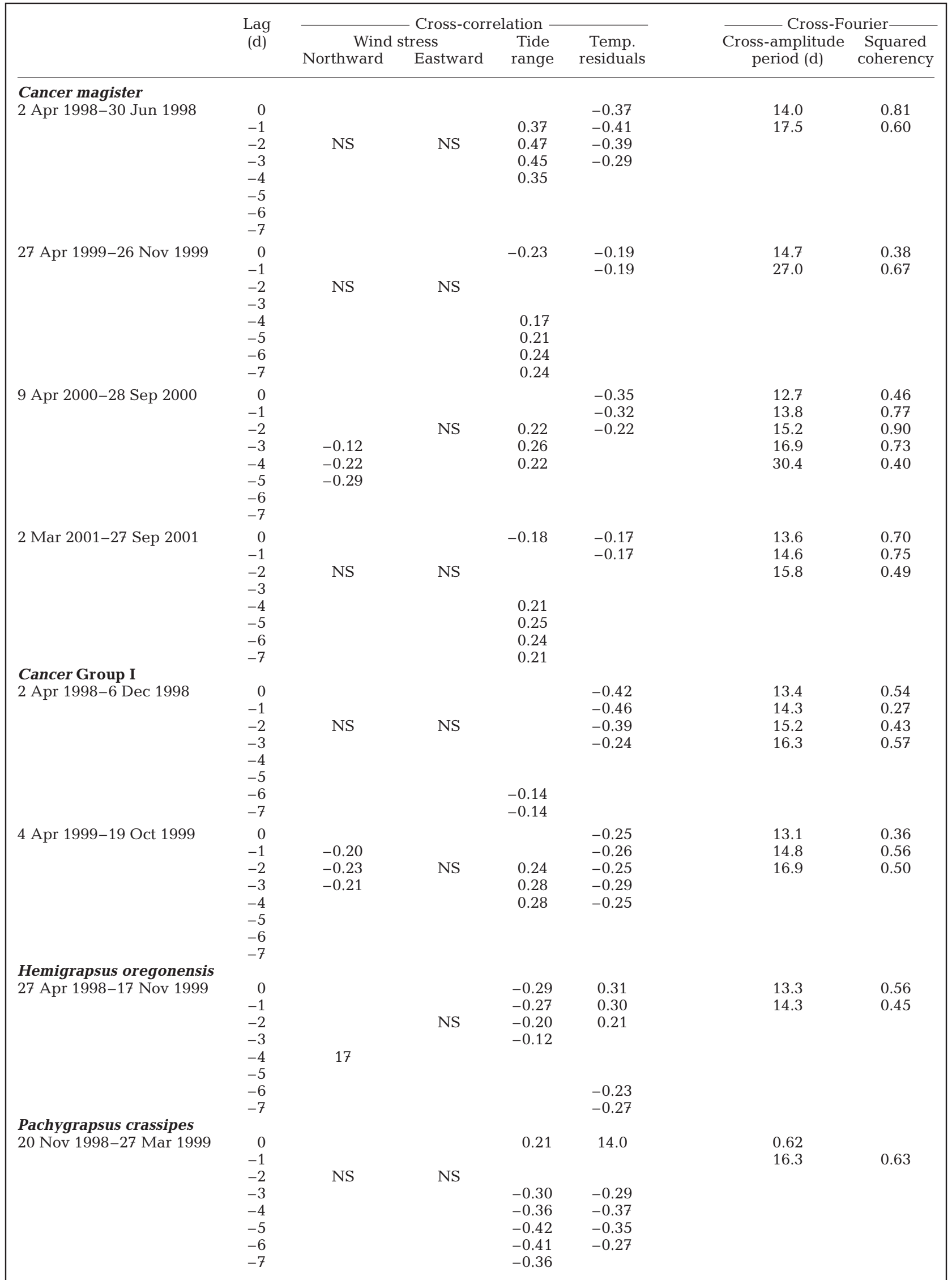


amplitudes maximum occurred at 14.0 and $16.3 \mathrm{~d}$ periods, and the tidal range explained between 62 and $63 \%$ of the variability, respectively (Table 2 ).

\section{Temperature variation and crab abundance}

In all years tested for both Cancer magister and Cancer Group I, significant negative correlations were found between the daily temperature residuals and catch, suggesting that peak catches tended to occur in association with cold water events (maximum negative correlations at lags of 0 to $-1 \mathrm{~d}$, except Cancer Group I in 1999, with a maximum at -4 d lag) (Table 2). In contrast, Hemigrapsus oregonensis catch was found to have significant positive cross-correlations with the daily temperature residuals at lags of 0 to $-1 \mathrm{~d}$, suggesting that peak catch occurred during warm water events (Table 2). Pachygrapsus crassipes exhibited less distinct results and had significant positive correlations at lags of 0 and $-1 \mathrm{~d}$ and negative correlations at lags of -2 to $-4 \mathrm{~d}$, perhaps indicative of a transition from warm to cold conditions (Table 2). Note that ocean and estuary temperatures are more isothermal during winter downwelling conditions.

\section{DISCUSSION}

Variation in wind forcing was reflected in the estuarine temperature time series. On the event time scale of several days, wind events generated water temperature fluctuations in the estuary at 0 to $-3 \mathrm{~d}$ lags. Upwelling wind events resulted in the import of colder coastal water to the estuary. These cold water events generally persisted until wind stress declined to about $0.03 \mathrm{~N} \mathrm{~m}^{-2}$, after which temperatures increased. Downwelling winds and periods of low wind stress tended to induce warm-water events, which signalled that warmer offshore water had returned to the coast. These characteristics are consistent with an upwelling/ relaxation mechanism resulting in the alternating advection of cold subsurface and warm surface waters, first to the coast and subsequently into the estuary, in response to variation in wind stress. During the upwelling season, this mechanism appears responsible for the transport of coastally-derived phytoplankton to northeast Pacific estuaries (Roegner \& Shanks 2001, Roegner et al. 2002).

However, we found little evidence to support the hypothesis that local wind-relaxation correlates to crab recruitment. Of the 4 crab groups we monitored, only Hemigrapsus oregonensis exhibited (in 1998) a response consistent with the relaxation model. Other species' recruitments had no relation to wind stress or had increased abundance during active upwelling. Inspection of the time series plots of the event-scale data shows that Cancer magister megalopae (for which we have the most extensive data) entered the estuary under a variety of wind states (Fig. 2). We conclude that variation in local wind-driven circulation is not a strong determinant of day-to-day variation in crab recruitment to Coos Bay.

In contrast, we consistently found significant crosscorrelations between the maximum daily tidal range and the catch of megalopae. However, there were no strong correlations of megalopae with maximum tidal range at or near $0 \mathrm{~d}$ lag, indicating crab abundance was not a simple function of increased advection with the larger volume transport during spring tides. These results indicate that variation in megalopae catch varied with the spring-neap cycle, but that larvae entered the estuary at different periods of the synodic month.

The results from this $3.75 \mathrm{yr}$ study are generally consistent with Cancer magister (the focus of many studies) recruitment variation measured during shorter duration studies in the northeast Pacific. In Coos Bay, Johnson \& Shanks (2002) used a moored net system to measure daily abundance of C. magister and Cancer Group I megalopae during spring 1997. Catches of megalopae were correlated only to maximum daily tidal range, with peak catches tending to occur around neap tides. Miller \& Shanks (2004) also used light traps to compare abundance of crab and fish larvae between a sample site at the outer coast near Coos Bay and a site within the estuary during spring 2000. C. magister abundance at outer coast and estuarine sites were correlated at 0 to -2 d lags, and highest estuarine abundance tended to occur between spring and neap tide and during cold water events, in agreement with our results. However, they also found associations with upwelling events. Further north, Roegner et al. (2003) investigated $C$. magister recruitment to Willapa Bay and Grays Harbor, Washington during a strong upwelling-relaxation event in 1999. Between estuaries and ocean, there was a tight coupling between water properties (temperature, salinity, and chlorophyll) and variation in wind stress (Roegner et al. 2002). However, C. magister megalopae in both ocean and estuarine samples were found throughout the range of water property values encountered and were not tightly linked to wind or tidal forcing. There was also little synchrony of C. magister recruitment between the 2 estuaries.

Variation in the catch within an estuary may be due to variations in the cross-shelf transport of megalopae, the ingress of megalopae into the estuary, or a combination of both. Miller \& Shanks (2004) found correlations at 0 to $-2 \mathrm{~d}$ lag between the catch of Cancer magister megalopae at an outer coast sample site and within the Coos estuary, suggesting that the variation in 
catch is due primarily to variation in the cross-shelf delivery of megalopae to the coast. In summary, the data for northeast Pacific estuaries suggest that the dominant mechanism for shoreward transport of megalopae is a sum function of the spring to neap tidal cycle.

All the studies cited above that employed surface light traps or nets measured larval abundance on a temporal scale that allows for a 2 to $4 \mathrm{~d}$ resolution of the physical drivers. This is a minimal sampling period necessary to ascertain effects due to variation in local wind events ( 2 to $10 \mathrm{~d}$ ) and is also suitable for spring-neap tide periods (14 $\mathrm{d}$ and multiples). Even with a daily sampling regimen, our data are inadequate for testing other processes that may be facilitating larval transport, such as semidiurnal or higher frequency tidal effects or land-sea breeze transport. Sample periods at weekly or longer intervals cannot detect recruitment events associated with the spring neap tidal cycle or even those caused by wind events (e.g. Wing et al. 1995a,b).

Larval abundances of a number of decapod taxa vary with the fortnightly tidal cycle. These include crab megalopae (including Cancer Group I, Pachygrapsus crassipes, Hemigrapsus spp., and majid crabs) in southern California (Shanks 2006), blue crab (Callinectes sapidus) megalopae at a number of sites along the US East Coast (Mense et al. 1995, Olmi 1995, van Montifrans et al. 1995, Shanks 1998), megalopae of a variety of crab species in Barbados (Reyns \& Sponaugle 1999), and spiny lobster puerulus in Florida (Little 1977). In addition, the settlement of barnacle cyprids in southern California varies with the fortnightly tidal cycle (Shanks 1986, Pineda 1991). These studies, as well as those from the northeast Pacific, all suggest that cross-shelf transport of crustacean larvae is dominated by tidal forcing.

Recent recruitment studies outside the northeast Pacific region indicate that both wind and tidal forcing may influence larval transport to coastal sites or to estuaries. In central California, Rougham et al. (2005) found that brachyuran recruitment to a rocky headland occurred under all wind conditions, but generally increased during upwelling periods. The authors suggest local nearshore retention mechanisms can enhance settlement rates. On the central Portuguese coast, Flores et al. (2002) found that onshore-offshore winds-but not relaxation from alongshore (upwelling) winds - correlated with intertidal crab settlement patterns. However, the cross-shore wind direction had reverse effects on the 2 most abundant species, which the authors contend was due to different vertical distributions of the larvae. Tides were found to have a secondary effect on settlement of the most abundant species. Queiroga et al. (2006) concluded that both relaxation from upwelling and tide influence the recruitment of Carcinus maenas to estuaries situated on the west coast of Portugal. Cross- correlation analysis indicated larval abundance was highest around spring tide conditions. In contrast, Narváez et al. (2006) made daily settlement measurements on rocky coasts of central Chile. Based on temperature and wind records, the relaxation transport model was not found to adequately explain settlement variation of intertidal invertebrates (op. cit.).

The daily abundance of crab megalopae arriving at Coos Bay varied with the fortnightly spring-neap tidal cycle, suggesting that the megalopae are transported shoreward by some tidally driven mechanism. Two general processes may account for these observations: megalopae may be exploiting either tidalstream transport on the shelf or the internal tides. At present we can only speculate which mechanism is utilized by species in the CCS, since testing these alternatives requires concurrent highfrequency sampling of both horizontal velocities and larval abundance.

Within estuaries, a number of species have been observed to utilize selective tidal-stream transport to move against or resist mean seaward advection (Forward \& Tankersley 2001), and the possibility of a tidal stream transport mechanism in shelf waters is intriguing (Hill 1995, Queiroga \& Blanton 2004). Spectral analyses of horizontal current velocities in shelf waters show that variance is concentrated at semidiurnal frequencies, and horizontal flows are often sheared with depth (Largier et al. 1993). Many invertebrate larvae are capable of vertical swimming speeds that would enable them to exploit this vertical shear in the horizontal currents over tidal time scales (Hill 1995). Larvae utilizing tidally-driven shelf currents could impart a directed cross-shelf transport throughout the springneap cycle if the ascent/decent migration phases were coordinated to the rotary tidal currents. Note that no water property or physical correlate measured at the estuary is required or expected with this mechanism.

Roughan et al. (2005) modeled larval vertical migration within a retention area in Bodega Bay, California and found vertical position strongly affected dispersal trajectory. However, it has not been demonstrated that crab larvae in the CCS possess the necessary circatidal vertical migration patterns. Most studies of Dungeness crab larvae in the CCS have concluded that abundance patterns conform to a diel vertical migration pattern (e.g. Hobbs \& Botsford 1992), which would generally not result in retention or directed horizontal displacements (Hill 1995). Timed vertical migration behavior relative to tidal currents is a plausible yet unconfirmed mechanism for cross-shore transport of crab megalopae on the Oregon shelf.

Alternatively, shoreward migration can be driven by the internal tides. Three transport mechanisms have been suggested: (1) surface convergence in internal waves (Shanks 2002), (2) bores or broken internal 
waves (Pineda 1991, Leichter et al. 1998, Shanks \& McCulloch 2003), and (3) cold bore upwelling fronts (Pineda 1999). If the transport is associated with a cold bore, then peaks in abundance should occur during cold water anomalies; transport in the convergence of internal waves could occur during any stage of the tidal cycle when large amplitude internal waves are generated. In our data, Cancer magister and Cancer Group I peak catches tended to occur during cold water anomalies, while the reverse was true for grapsid crabs. Very similar results were found in time-series of daily megalopal abundance collected in southern California (Shanks 2006). These results from 2 separate locations support cancer crab transport by cold internal bores. In contrast, megalopae of grapsid crabs were most abundant during warm water anomalies, suggesting that transport may be in the convergence over tidally generated internal waves, a process that has been observed for grapsids in southern California as well as different taxa in other locations (Shanks \& Wright 1987). Pineda (1995) found negative temperature anomalies (characteristic of breaking internal waves, i.e. bores) were common at 10 US West Coast stations in spring and summer, and that they occurred most commonly near neap tide periods. Again, higher frequency biological and physical sampling is required to confirm that these tidal mechanisms operate to influence crab recruitment on the Oregon shelf.

In summary, over a 3.75 yr period, we measured estuary exchange events forced by wind but failed to find consistent correspondence to crab recruitment events. Instead, catches of crab megalopae exhibited a fortnightly periodicity in abundance, and were significantly cross-correlated to maximum daily tidal range in most cases. The lag in the cross-correlation with tidal range suggests entrance into the estuary during neap tides or the period between spring and neap, but little association with spring tides. These results indicate that some tidal mechanism, probably associated with the internal tides, controls the cross-shelf transport and entry of crab megalopae to the Coos Bay estuary.

Acknowledgements. This paper is a result of research funded by the National Oceanic and Atmospheric Administration Coastal Ocean Program under award \# NA96OP0238 to the University of Washington. We thank J. Miller, our colleagues on the PNCERS project, and 3 reviewers for contributions that improved the manuscript.

\section{LITERATURE CITED}

Connell JH (1985) The consequences of variation in initial settlement vs post-settlement mortality in rocky intertidal communities. J Exp Mar Biol Ecol 93:11-45

Flores AAV, Cruz J, Paula J (2002) Temporal and spatial patterns of settlement of brachyuran crab megalopae at a rocky coast in Central Portugal. Mar Ecol Prog Ser 229: $207-220$

Forward RBJ, Tankersley RA (2001) Selective tidal-stream transport of marine animals. Oceanogr Mar Biol Ann Rev 39:305-353

Hickey BM (1989) Patterns and processes of circulation over the shelf and slope. In: Hickey BM, Landry MR (eds) Coastal oceanography of Washington and Oregon. Elsevier, New York, p 41-115

Hickey BM, Banas N (2003) Oceanography of the U.S. Pacific Northwest coastal ocean and estuaries with application to coastal ecology. Estuaries 26:1010-1031

Hill AE (1995) The kinematical principles governing horizontal transport induced by vertical migration in tidal flows. J Mar Biol Assoc UK 75:3-13

Hobbs RC, Botsford LW (1992) Diel vertical migration and timing of metamorphosis of larvae of the Dungeness crab, Cancer magister. Mar Biol 112:417-428

Huyer A (1983) Coastal upwelling in the California current system. Prog Oceanogr 12:259-284

Johnson J, Shanks A (2002) Time-series of the abundance of post-larval Cancer magister and Cancer spp. on the southern Oregon coast and their cross-shelf transport. Estuaries 25:1138-1142

Largier J, Magnell BA, Winant CD (1993) Subtidal circulation over the northern California shelf. J Geophys Res 98: 18147-18179

Leichter JJ, Shellenbarger G, Genovese SJ, Wing SR (1998) Breaking internal waves on a Florida (USA) coral reef: a plankton pump at work? Mar Ecol Prog Ser 166:83-97

Little EJJ (1977) Observations on recruitment of postlarval spiny lobsters, Panulirus argus, to the south Florida coast. Florida Marine Research No. 29, Florida Marine Institute, St. Petersburg, FL

Mense DJ, Posey MH, West T, Kincheloe T (1995) Settlement of brachyuran postlarvae along the North Carolina coast. Bull Mar Sci 57:793-806

Miller JA, Shanks AL (2004) Ocean-estuary coupling in the Oregon upwelling region: abundance and transport of juvenile fish and crab megalopae. Mar Ecol Prog Ser 271: $267-279$

Narváez DA, Navarrette SA, Largier J, Vargas CA (2006) Onshore advection of warm water, larval invertebrate settlement, and relaxation of upwelling off central Chile. Mar Ecol Prog Ser 309:159-173

Olmi EJI (1995) Ingress of blue crab megalopae in the York River, Virginia 1987-1989. Bull Mar Sci 57:753-780

Pedlosky J, (1987) Geophysical fluid mechanics. SpringerVerlag, New York

Pineda J (1991) Predictable upwelling and the shoreward transport of planktonic larvae by internal tidal bores. Science 253:548-551

Pineda J (1995) An internal tidal bore regime at nearshore stations along western USA: predictable upwelling within the lunar cycle. Cont Shelf Res 15:1023-1041

Pineda J (1999) Circulation and larval distribution in internal tidal bore warm fronts. Limnol Oceanogr 44:1400-1414

Pyper BJ, Peterman RM (1998) Comparison of methods to account for autocorrelation in correlation analyses of fish data. Can J Fish Aquat Sci 55:2127-2140

Queiroga H, Blanton JO (2004) Interactions between behaviour and physical forcing in the control of horizontal transport of decapod crustacean larvae: an overview. Adv Mar Biol 47:107-214

Queiroga H, Almeida MJ, Alpuim T, Flores AAV and 5 others (2006) Tide and wind control of megalopal supply to estuarine crab populations on the Portuguese west coast. 
Mar Ecol Prog Ser 307:21-36

Reyns N, Sponaugle S (1999) Patterns and processes of brachyuran crab settlement to Caribbean coral reefs. Mar Ecol Prog Ser 185:155-170

Roegner GC, Shanks AL (2001) Import of coastally-derived chlorophyll a to South Slough, Oregon. Estuaries 24: 224-256

Roegner GC, Hickey BM, Newton JA, Shanks AL, Armstrong DA (2002) Wind-induced plume and bloom intrusions into Willapa Bay, Washington. Limnol Oceanogr 47: 1033-1042

Roegner GC, Armstrong DA, Hickey BM, Shanks AL (2003) Ocean distribution of Dungeness crab megalopae and recruitment patterns to estuaries in southern Washington State. Estuaries 26:1058-1070

Roughan M, Mace AJ, Largier J, Morgan SG, Fisher, JL (2005) Subsurface circulation in the lee of a small headland: a variation on the upwelling shadow theme. J Geophys Res 110:C10027, doi: 10.1029/2005JC002898

Roughgarden J, Pennington JT, Stoner D, Alexander D, Miller K (1991) Collisions of upwelling fronts with the intertidal zone, the cause of recruitment pulses in barnacle populations of central California. Acta Oecologia 12: $35-51$

Send U, Beardsley RC, Winant CD (1987) Relaxation from upwelling in the Coastal Ocean Dynamics Experiment. J Geophys Res 92:1683-1698

Shanks AL (1983) Surface slicks associated with tidally forced internal waves may transport pelagic larvae of benthic invertebrates and fishes shoreward. Mar Ecol Prog Ser 13: 311-315

Shanks AL (1986) Tidal periodicity in the daily settlement of intertidal barnacle larvae and an hypothesized mechanism for the cross-shelf transport of cyprids. Biol Bull 170: $429-440$

Shanks AL (1995) Mechanisms of cross-shelf dispersal of larval invertebrates and fish. In: McEdward LR (ed) Ecology of marine invertebrate larvae. CRC Press, Boca Raton, FL, p 324-367

Shanks AL (1998) Abundance of post-larval Callinectes sapidus, Penaeus spp., Uca spp., and Labinia spp. col-

Editorial responsibility: Jon Hare (Contributing Editor), Narragansett, Rhode Island, USA lected at an outer coastal site and their cross-shelf transport. Mar Ecol Prog Ser 168:57-69

Shanks AL (2002) Internal tides and the biology of continental shelf waters. In: Largier J (ed) The oceanography and ecology of the nearshore and bays in Chile. Universidad Catolica de Chile, Santiago, p 3-27

Shanks AL (2006) Mechanisms of cross-shelf transport of crab megalopae inferred from a time series of daily abundance. Mar Biol 148:1383-1398

Shanks AL, Eckert G (2005) Life-history traits and population persistence of California Current fishes and benthic crustaceans; solution of a marine drift paradox. Ecol Monogr 75:505-524

Shanks AL, McCulloch AA (2003) Fortnightly periodicity in the abundance of diatom and dinoflagellate taxa at a coastal study site. J Exp Mar Biol Ecol 296:113-126

Shanks AL, Roegner GC (2007) Recruitment-limitation in Dungeness crab populations is driven by temporal variation in atmospheric forcing. Ecology 88:1726-1737

Shanks AL, Wright WG (1987) Internal-wave-mediated shoreward transport of cyprids, megalopae, and gammarids and correlated longshore differences in the settling rate of intertidal barnacles. J Exp Mar Biol Ecol 114:1-13

Sinclair M (1988) Marine populations: an essay on population regulation and speciation. Washington Sea Grant Program, Seattle, WA

Strub PT, Allen JS, Huyer A, Smith RL (1987) Large-scale structure of the spring transition in the coastal ocean off western North America. J Geophys Res 92:1527-1544

van Montifrans J, Epifanio CE, Knott DM, Lipcius RN and 7 others (1995) Settlement of blue crab postlarvae in western North Atlantic estuaries. Bull Mar Sci 57: $834-854$

Wing SR, Botsford LW, Largier JL, Morgan LE (1995a) Spatial structure of relaxation events and crab settlement in the northern California upwelling system. Mar Ecol Prog Ser 128:199-211

Wing SR, Largier JL, Botsford LW, Quinn JF (1995b) Settlement and transport of benthic invertebrates in an intermittent upwelling region. Limnol Oceanogr 40: $316-329$

Submitted: July 10, 2006; Accepted: June 25, 2007

Proofs received from author(s): November 9, 2007 